\title{
Research on Real Estate Appraisal Development Based on Property Tax Reform
}

\author{
Shan-Shan Ye ${ }^{1, a,{ }^{*}}$, Yu Qin ${ }^{2, b}$ \\ ${ }^{1}$ School of Management, China University of Mining and Technology (Beijing), Beijing, 100083 China \\ ${ }^{2}$ Institute of Space and Earth Information Science, The Chinese University of Hong Kong, Hong Kong

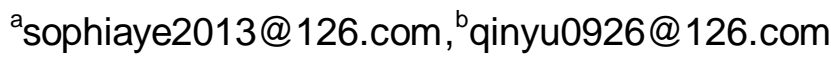 \\ ${ }^{*}$ Corresponding author
}

Keywords: Property tax, Real estate appraisal, Mass appraisal, Appeal mechanism.

\begin{abstract}
With the rapid development of China's real estate industry, pushing forward property tax levy timely has become an inevitable trend of economic reforms. To ensure the feasibility and operability of property tax levy and realize the coordinated development between real estate appraisal and property tax reform, it is crucial to scientifically set up the tax base and appraisal principles for property tax levy, consider the application scope of real estate appraisal methods, creatively apply the mass appraisal technology and improve the professional skills of the personnel.
\end{abstract}

\section{Introduction}

Property tax is a kind of tax levied according to its assessment value on real estate like land, houses and so on. Tenant or owner of real estate should pay certain taxes every year, and the amount varies as the market value changes [1]. It is a basic element of levying property tax to set the tax basis of property tax scientifically. From international experience, it is widely used among various countries to regard the market value of real estate as tax basis. It conforms to ability-to-pay principle and also has many advantages, such as the rich tax sources, the good elasticity of income, the plentiful transaction basis, and the facilitative of tax-paying by credibility [2-3].

\section{The necessity and feasibility of property tax basis reform}

According to the statistics, more than 130 countries around the world levy a variety of property tax. In order to adapt to the challenges of economic globalization, countries such as Britain, Japan, and the Netherlands have already carried out the property tax reform. In central and eastern European countries with economies in transition, it is even considered as an important step to promote national political and economic system reform [4].

Reforming the existing real estate tax system and implementing property tax have been put on the agenda of the government. Reform of tax basis in property tax is an important content of this reform. From initial proposal to further discussion, and then the clear attitude towards the study of the implementation scheme of property tax, it creates necessary prerequisite to the successful implementation of property tax in the future. Among them, the State Administration of Taxation has carried out the simulative pilot work in Beijing, Shenzhen and other places. They operate the appraisal work of tax basis in property tax simulatively. This provides valuable experience for the promotion of appraisal works nationwide and reference for the official implementation of property tax.

The thriving real estate market provides a good hardware and software environment. In the recent 10 years, the real estate industry in our country keeps sustained and rapid growth. The growth of real estate investment and commercial housing sales are both more than two digits. Meanwhile, after more than ten years development, real estate appraisal industry in our country has made great progress, which has already been an integral intermediary of the real estate market. According to the statistics, there are more than 3000 registered real estate appraisal institutions in our country. These institutions engage in relevant work over a long period of time which explored and accumulated rich experiences for the development of real estate appraisal industry in our country. 
The informatization of tax authority provides an operational platform. Ideal computer management system is an essential factor for the real estate tax appraisal. After nearly a decade efforts, the infrastructure of tax information system has begun to take shape, which has made great progress in hardware configuration, policies and regulations, business process, technology and so on. A relatively complete tax management information system is forming, which includes hardware, network and application sub-systems. All of these provide the necessary technical support and operational platform for the realization of the real estate tax appraisal.

\section{Relevant problems of real estate appraisal}

\section{The establishment of the appraisal principles}

Real estate appraisal in the process of property tax levy is required to establish suitable principles.

Legality. Real estate appraisal should follow the relevant laws, regulations and policies in our country. It is necessary to cognize the legitimacy of the real estate appraisal objects, on the basis of which appraise the real estate, and then realize the unification between the financial interests of state, the legitimate rights and interests of taxpayers.

Reference date. Spatiotemporal variability of real estate shows that the same property may change as time changes. According to the specific requirements of levy, it requires reasonable setting appraisal data which will reflect the changes of real estate value.

Substitution (also called the principle of comparison). For object of real estate appraisal, its price is replaced through various kinds of comparison with trade prices in the market of close region, similar type and the same use. This could simplify the appraisal process that reduces the cost.

Fairness. In the process of appraisal, in order to ensure the rights, interests of taxpayers and promote the reputation of appraisal industry, it is required not only to follow the theory and law of the prices of real estate, but also to appraisal prices of real estate objectively in scientific methods.

\section{The methods of appraisal and the selection of techniques}

Main methods of real estate appraisal and their comparison. There are three basic kinds of appraisal methods, namely the current market value method (market comparison method), income present value method (income revivification method) and replacement cost method (cost method).

Current market value method is an appraisal method which compares the appraisal object with similar real estate that is transacted recently, revises the price of this similar real estate properly, and regards this as objective and reasonable price of appraisal object on appraisal point. It is applicable to develop real estate market, which has plenty of alternative instances areas. However, it is difficult to apply to ancient buildings and schools which are rarely traded. Income revivification method is an appraisal method which calculates the expected objective income every year in the future to the appraisal date by a certain capitalization rate (reduction rate). Replacement cost method is an appraisal method which calculates the prices of reset or reconstruction of appraisal objects at appraisal point, deducts depreciation, and then estimates the objective and reasonable prices or values of real estate.

Based on the revision of transaction price of real estate in similar transactions, market comparison method gains the market comparison approach prices. However, in order to ensure the accuracy of the revision, it must satisfy a certain number of transaction materials, it has certain limitations for real estate which lacks transaction material and is rarely traded. Income revivification method calculates the expected income in the future to present value of the appraisal date by a reasonable interest rate. Both the uncertainty of expected return, interest rates in the future and the distinction between tangible and intangible value increase the technical difficulty of its application. Replacement cost method is applied to non-income and rarely transaction case. Regional features of real estate lead natural flaws of the replacement cost method. It cannot reasonably reflect the effective prices of real estate; therefore, its applicable scope is narrow.

According to the discussion above, the three methods still have great limitations in a certain level because of the various features of real estate. Single method of appraisal has great difficulties in dealing 
with multiple property objects. Therefore, it is necessary to update and improve the existing methods to promote the research on the changes of the real estate market.

Mass appraisal technology. The cost of monomer appraisal of the real estate as the tax base of property tax stays at a high level. In order to ensure the efficiency of levying property tax, control the costs of levying and improve the impartiality, rationality of the appraisal results, the promotion of mass appraisal technology is particularly important. The mass appraisal of tax base has been widely used among the countries levying a tax on real estate. The process of mass appraisal includes three steps:

Determine influence factors of the value of real estate in our country and build up preliminary database framework on this basis. Based on the understanding of the domestic real estate market, to determine the main influencing factors of the real estate value, and explore value attributes of the influencing factors. Handle the internal architecture of database and its ductility correctly, and build the database framework of the appraisal of property tax base.

Update data collection channels and set up automatic appraisal model. By acquiring relevant data from government agencies, real estate trading center and the asset appraisal companies, ensure the stability, reliability and accuracy of the data source. At the same time, sort and store the acquired basic information of real estate, including position of real estate, land area, allowable usage, area of buildings and so on. Then, begin the construction of large-scale database and model test of large sample, and improve the function of data accumulation and measured model. Complete the construction of automatic appraisal model.

Experiments and the formal implementation. Tax on the pilot area using mass appraisal levy system, and then explore its fairness and operability. Based on the work in pilot areas, promoting the mass appraisal technology gradually to make it perfect and practical.

In the realization of the mass appraisal, computers are needed as an auxiliary tool. Therefore, the method used in mass appraisal in practice is often "Computer - Aided Mass Appraisal" (CAMA.). The application of this technology requires the storage of the transaction information into the database of computers, analysis of the market by computer applied regression technology, and structure appraisal model. The appraisal value will be output after the input of the basic information of real estate appraisal object. The widely-used CAMA technology greatly improves the efficiency of tax base appraisal, increases the transparency, and reduces the cost and the interference of human.

\section{Personnel education}

Compared with other taxation, appraisal tax of real estate is more complicated with higher technical requirementsand more powerful policy, thus, it is very necessary ensuring the education to personnel. On the basis of knowledge structure analysis of workers, besides the professional tax and financial knowledge, they also shouldgrasp the following professional knowledge and abilities:

Appraisal techniques and approaches. They should be able to master all kinds of professional techniques and knowledge on real estate appraisal and real estate value, handle the uncertainty elements in the process of appraisal timely, and ensure the accuracy and reasonability of appraisal the real estate value, which can be close to market value and reflect the market supply-demand relationship. Then, they not only need to guarantee the government financial revenue that should increase as the economic increases, but also protect the legitimate rights and interests of taxpayers. Thus, they will promote the healthy development of real estate industry.

The stuff should grasp the development status of real estate industry timely, understand the information of market, and be able to analyze and forecast the development trend of real estate industry accurately. Thus, the tax appraisal work will be carried out effectively.

They should be familiar with the relevant laws, regulations and administration system on urban construction and real estate development, and clear the legal basis of tax appraisal work.

\section{The construction of the appeal mechanism}

There are amounts of work in tax appraisal basis of real estate, in which elements and technical problems involved are more complex. It is inevitable for taxpayers to have divergence in valuation. Therefore, ensuring the rights of taxpayers to appeal against the result of appraisal, relevant laws and regulations are deeply needed. Firstly, from the aspect of organization, specialized review committees 
which are independent of appraisal departments should be set up throughout the country. Moreover, appraisal expert group should be organized, in which the experts should keep independent and authoritative. To make sure the consistency and fairness of tax, the review committees mainly handle the taxpayers' appeals. At the same time, the principle of "who appraise, who accept appeal" can also be followed. That is to say, if tax authority or intermediary is entrusted by tax authority appraise, they should also accept the appeals. If housing authority gives the appraisal result and tax authority is in charge of collection, the housing authority should accept the taxpayers' appeals for appraisal result.

Secondly, to ensure taxpayers' rights to know, tax authority should publish the initial results and materials of real estate on relevant media or websites before formal levy after they appraise the tax basis of real estate, and they should give a certain period of appeal. During the period of appeal, if the owner holds different opinions to the price of tax appraisal, he can appeal to the appraisal agency. And the owner may apply for a review to local review committee; the review committee shall notify the result to the owner and relevant appraisal agency in written form as soon as possible. The final price of tax appraisal takes the result of the review committee as criterion.

\section{Suggestions and countermeasures}

The accelerated economic and social development in our country, especially the urbanization process, promotes the development of real estate industry greatly. The existing management of real estate tax has already lagged behind. It has been the general trend to draw lessons from international experience, carry out the tax appraisal of real estate in time, implement the macro economic and social policies of government, and realize the virtuous cycle between economy and tax. Therefore, at present, it is necessary to consider and research the conditions of a property tax in our country, estimate the current political and economic environment correctly, explore potential problems during the implementation of the tax system and possible measures taxpayers may take, establish the standard of tax appraisal techniques in detail, adopt various technical means, and appraise value of real estate accurately. In order to guarantee smoothly operation of the tax appraisal, a technical information system must be scientifically established. Besides, the taxation relationship of real estate should be regulated to increase government revenue. A high-quality and high-level professional team of real estate tax appraise should also be cultivated.

\section{References}

[1] Zhang Xiaofeng, Ye Shanshan, Ho Shi Tao. Research on the Reform of Property Tax in Foreign Countries and Its Enlightenment to China [J]. Business Accounting, 2012, (13).

[2] Chu Zhaoming, International Comparison and Reference of Real Estate Tax Appraisal [J]. Taxation Research. 2008, 4:86-88.

[3] Fan Huixia, International Experience and Optimizing Design Study on the Real Estate Tax Preferential Policy [J]. Journal of Inner Mongolia University (Philosophy and Social Sciences), 2012, 44(1):15-19.

[4] Chen Xiaoyue, Sun Liqiang, A Reflection on the Construction of Mass Appraisal System of Real Estate Tax in China [J]. Public Finance Research, 2007, 12:48-51. 